\title{
The relationship between semen seminal plasma ions and sperm cell velocities of wild-caught longspine scraper, Capoeta trutta
}

\author{
Mustafa Erkan Özgür ${ }^{1}$, Zeynep Maraş ${ }^{2}$, and Selim Erdoğan ${ }^{2}$ \\ ${ }^{1}$ Department of Aquaculture, Faculty of Fishery, Malata Turgut Özal University, 44210, Malatya, Turkey \\ ${ }^{2}$ Department of Analytical Chemistry, Faculty of Pharmacy, İnönü University, 44280, Malatya, Turkey \\ Correspondence: Mustafa Erkan Özgür (mustafa.ozgur@ozal.edu.tr)
}

Received: 13 March 2019 - Revised: 15 September 2019 - Accepted: 17 September 2019 - Published: 26 September 2019

\begin{abstract}
In this study, semen seminal plasma contents and the motility of sperm cells were determined in Capoeta trutta via a computer-assisted sperm analysis system. In addition, we evaluated the relationship between semen seminal plasma ions and the velocities of sperm cells. Although the predominant ions were $\mathrm{K}(206.84 \pm$ $\left.20.61 \mathrm{mg} \mathrm{L}^{-1}\right)$ and $\mathrm{Na}\left(128.06 \pm 23.82 \mathrm{mg} \mathrm{L}^{-1}\right)$ in the semen seminal plasma, $\mathrm{Ca}\left(14.05 \pm 4.13 \mathrm{mg} \mathrm{L}^{-1}\right)$ and $\mathrm{Mg}\left(3.35 \pm 0.44 \mathrm{mg} \mathrm{L}^{-1}\right)$ were not predominate according to our results. However, partially strong relationships between the curvilinear velocity value (VCL) and $\mathrm{K}\left(R^{2}=0.67 ; p<0.05\right)$ were found, while it was moderate with $\mathrm{Mg}\left(R^{2}=0.48 ; p<0.05\right)$. There was a weak relationship with $\mathrm{Na}\left(R^{2}=0.17 ; p<0.05\right)$ and $\mathrm{Ca}\left(R^{2}=\right.$ $0.34 ; p<0.05)$. In our results, while the trace metals were determined as $\mathrm{Zn}>\mathrm{Al}>\mathrm{B}>\mathrm{Li}>\mathrm{Cu}$ in semen seminal plasma, they are not correlated with sperm cell velocities. Finally, we hope that the present information on the motility parameters of Capoeta trutta in this paper will eventually help artificial insemination in reproduction practices.
\end{abstract}

\section{Introduction}

Capoeta trutta (Heckel, 1843) is a species in the Cyprinidae family. The fish species is distributed in the Euphrates and Tigris rivers in Turkey, Iran, Iraq, and Syria (Esmaeili et al., 2010; Demirsoy, 1993). Capoeta trutta has been listed as "least concern" on the IUCN Red List of Threatened Species since 2014, but its population has been decreasing in its natural habitat because of overfishing and water pollution (Freyhof, 2014).

The aquatic species should be domesticated because commercial aquaculture has developed very rapidly, and threatened populations have needed additional restoration in wild habitats (Lorenzen et al., 2012). However, the control of quality gametes is important for the performance of brood stocks in aquaculture systems. Therefore, the semen quality is very important for fish farming industry, commercial species, and biotechnological applications (Bobe and Labbé, 2010; Cabrita et al., 2014; Şahinöz et al., 2008). The motility, duration of motility and density, $\mathrm{pH}$, spermatocrit, and sem- inal plasma contents are major parameters to determine the semen quality in fish (Billard and Cosson, 1992; Rurangwa et al., 2004). However, seminal plasma has very important ions that support the viability, motility, or immobilization of sperm cells. In teleost fish species, the sperm cells are immobilized in the testes and seminal fluid, and the start of motility depends on the conditions of the fertilization environment. The ion concentrations $\left(\mathrm{Na}^{+}, \mathrm{K}^{+}, \mathrm{Ca}^{2+}, \mathrm{Mg}^{2+}\right.$, $\mathrm{HCO}_{3}^{-}$etc.), osmolality, and $\mathrm{pH}$ in activator media are among the most important to regulate motility of sperm cells, in addition to other factors (Alavi and Cosson, 2006; Browne et al., 2015; Dzyuba and Cosson, 2014). For example, rainbow trout sperm cells were inactivated after being diluted with solutions containing high concentrations of the $\mathrm{K}^{+}$ion. However, the isotonic $\mathrm{NaCl}$ solution triggers immediate activation of sperm cell motility (Alavi and Cosson, 2006). For the motility of rainbow trout sperm cells, $\mathrm{Na}^{+} / \mathrm{H}^{+}$exchange may also be responsible for the participation of $\mathrm{Na}^{+}$ ions (Dzyuba and Cosson, 2014). However, researchers have found that intracellular $\mathrm{Ca}$ ion concentrations increase when 
the motility of sperm cells begins. Therefore, Ca ion concentration is a necessity for the motility of sperm cells (Alavi et al., 2011; Alavi and Cosson, 2006; Cosson et al., 1989; Tanimoto and Morisawa, 1988). However, some trace elements such as $\mathrm{Zn}, \mathrm{Mg}, \mathrm{Cu}$, and $\mathrm{Ca}$ are important for the maintenance of normal spermatogenesis, sperm maturation, and DNA metabolism (Yuyan et al., 2008). There are some studies that associated trace elements with the parameters of oxidative stress and sperm cell motility in Acipenser ruthenus (Li et al., 2010); there are also associated relationships between trace elements and sperm cell motility in Cyprinus carpio (Kovacik et al., 2018), Barbus grypus (Ögretmen et al., 2014), the levels and effects of trace elements of semen seminal plasma in infertile men (Bassey et al., 2013; Vickram et al., 2013), and bovine semen (Tvrdá et al., 2013). Computer-assisted sperm analysis (CASA) systems are very popular for the practical analysis of sperm cell motility in various species and have combined the methods of predicting the analyzer's emotions with classical methods used in the past (Fauvel et al., 2010; Özgür et al., 2019).

The reproduction properties of Capoeta trutta can help to understand their management, conservation in nature, and reproduction status in artificial conditions. Thus, we studied some parameters of reproduction, including sperm cell motility, sperm cell density, and the contents of semen seminal plasma.

\section{Material and methods}

\subsection{Semen sample collection}

Wild males of Capoeta trutta (weight: $350 \pm 20 \mathrm{~g}$, total length: $26 \pm 5.6 \mathrm{~cm}, N=10$ ) were caught at Karakaya Dam Lake in the upper part of the Euphrates River, Malatya Province, Turkey, on May 2018. The semen samples were collected without hormone injection. The sexual maturity of the fish was confirmed by the urogenital opening and breeding tubercles on the nose. Therefore, semen samples collected in Eppendorf tubes with gentle pressure to the abdomen. Then, they were rapidly transported in Styrofoam boxes with ice to the laboratory and were analyzed. Care was taken to avoid any contamination by urine during the collection of semen samples.

\subsection{The determination of sperm cell motility}

Fresh semen samples from 10 individual fish were diluted at a ratio of $1: 100$ with immotile solution (IMS) $\left(128.4 \mathrm{mM} \mathrm{NaCl}, 2.7 \mathrm{mM} \mathrm{KCl}, 1.4 \mathrm{mM} \mathrm{CaCl}{ }_{2}\right.$, $2.4 \mathrm{mM} \mathrm{NaHCO} 3$; pH 8.1) (Linhart et al., 2000) and were stored at $4{ }^{\circ} \mathrm{C}$ until the analysis was performed, $1 \mathrm{~h}$. Then, semen samples were activated under the microscope to determine the parameters of sperm cell motility at a ratio of $1: 20$ with activation solution (AS) $(\mathrm{mM} \mathrm{NaCl} ; 5 \mathrm{mM}$ $\mathrm{KCl} ; 20 \mathrm{mM}$ Tris-HCl, pH 8) (Linhart et al., 2000) at room temperature. Sperm cells were analyzed without coverslips. All semen samples were kept on ice and examined under an Olympus CX31 microscope with $200 \times$ magnification lens and a Sony CCD camera with $30 \mathrm{fbs}$ video recording capacity. The motility of sperm cells was analyzed via the computer-assisted sperm analysis system BASA-Sperm Aqua, produced by Merck Biotechnology Ltd. Co. in Turkey. The values of motility parameters such as VSL (straight line velocity, $\mu \mathrm{m} \mathrm{s}^{-1}$ ), VCL (curvilinear velocity, $\mu \mathrm{m} \mathrm{s}^{-1}$ ), VAP (angular path velocity, $\mu \mathrm{m} \mathrm{s}^{-1}$ ), LIN (linearity, \%, $(\mathrm{VSL} / \mathrm{VCL}) \times 100)$, BCF (beat cross frequency, Hz), ALH (amplitude of lateral displacement of the sperm cell head, $\mu \mathrm{m}$ ), and MAD (mean angular displacement, $\left({ }^{\circ}\right)$ ) (Fauvel et al., 2010; Özgür et al., 2019) are examined in the study. The following setting were used in the picture settings and parameters of BASA Sperm Aqua: acquired time delay of 0 , an image field maximum of 60; images per record of 90 , frame per second minimum of 30 , track immotile level of 5 , track motile level of 25 , velocity maximum of 500 .

The semen samples were diluted with $125 \mathrm{mM} \mathrm{NaCl}$ up to 16 -fold and determined in a spectrophotometer with the absorbance at $505 \mathrm{~nm}$ for sperm cell concentration (Ciereszko and Dabrowski, 1993).

\subsection{The analysis of semen seminal plasma ions}

Semen seminal plasma was collected after centrifugation of the semen at $3400 \mathrm{~g}$ for $10 \mathrm{~min}$ in Beckman L-8-70M ultracentrifuge (Rotor SW-28, Munich, Germany). Seminal plasma was centrifuged twice to avoid possible contamination with sperm cell and stored at $-20^{\circ} \mathrm{C}$ until analysis. The samples of semen were digested in the ultrasonic bath for $10 \mathrm{~min}$ by using $1 \mathrm{~mL} \mathrm{HNO}_{3}$. Digested solutions were diluted with deionized water until adjusted to $10 \mathrm{~mL}$. After dilution, they were analyzed for $\mathrm{Na}, \mathrm{K}, \mathrm{Ca}, \mathrm{Mg}, \mathrm{Al}, \mathrm{B}$, $\mathrm{Cu}, \mathrm{Li}$, and $\mathrm{Zn}$ (Massanyi et al., 2008; Özgür et al., 2015; Slivkova et al., 2009). Metal concentrations were determined by inductively coupled plasma optical emission spectrometry (ICP-OES VARIAN 725-ES, with CCD detector). All standard solutions $(0.01,0.05,0.1,0.2,0.5,1.0,2.0,5.0$, 10.0 , and $100 \mathrm{~m} \mathrm{~L}^{-1}$ ) were prepared by diluting $1 \mathrm{mg} \mathrm{mL}^{-1}$ stock multielement standard solutions for ICP-OES. The optimum instrumental parameters of ICP-OES were, for example, radiofrequency power $(1.2 \mathrm{~kW})$, plasma gas flow rate $\left(15.0 \mathrm{~L} \mathrm{~min}^{-1}\right)$, auxiliary gas flow rate $\left(1.5 \mathrm{~L} \mathrm{~min}^{-1}\right)$, nebulizer flow rate $\left(0.75 \mathrm{~L} \mathrm{~min}^{-1}\right)$, replicate read time $(3 \mathrm{~s})$, delay $(15 \mathrm{~s})$, sample uptake delay (30 s), pump rate $(15 \mathrm{rpm})$, rinse time (20 s), replicates (3), and torch (quartz for vertical view) for detection of multi-elements.

\subsection{Statistical analysis}

The relationships between all data were tested by using the bivariate correlation coefficients of Pearson. Then, linear and non-linear regression models were investigated between pa- 
Table 1. The motility parameters of sperm cells and semen seminal plasma contents in Capoeta trutta.

\begin{tabular}{|c|c|c|c|}
\hline$N=10$ & Mean \pm SD & Minimum & Maximum \\
\hline \multicolumn{4}{|c|}{ Motility parameters } \\
\hline $\operatorname{VSL}\left(\mu \mathrm{m} \mathrm{s}^{-1}\right)$ & $52.84 \pm 6.32$ & 43.17 & 63.99 \\
\hline $\operatorname{VCL}\left(\mu \mathrm{ms}^{-1}\right)$ & $103.86 \pm 22.67$ & 64.62 & 135.30 \\
\hline $\operatorname{VAP}\left(\mu \mathrm{ms}^{-1}\right)$ & $66.71 \pm 11.02$ & 43.42 & 79.67 \\
\hline $\operatorname{LIN}(\%)$ & $24.39 \pm 5.11$ & 16.33 & 41.38 \\
\hline $\mathrm{BCF}(\mathrm{Hz})$ & $9.21 \pm 1.90$ & 6.17 & 11.34 \\
\hline $\mathrm{ALH}(\mu \mathrm{m})$ & $37.69 \pm 7.49$ & 23.15 & 49.31 \\
\hline $\operatorname{MAD}\left({ }^{\circ}\right)$ & $0.02 \pm 0.01$ & 0.01 & 0.04 \\
\hline \multicolumn{4}{|c|}{ Seminal plasma contents } \\
\hline $\mathrm{Ca}\left(\mathrm{mg} \mathrm{L}^{-1}\right)$ & $14.05 \pm 4.13$ & 8.82 & 22.06 \\
\hline $\mathrm{K}\left(\mathrm{mg} \mathrm{L}^{-1}\right)$ & $206.84 \pm 20.61$ & 151.36 & 265.00 \\
\hline $\operatorname{Mg}\left(\mathrm{mg} \mathrm{L}^{-1}\right)$ & $3.35 \pm 0.44$ & 2.66 & 4.20 \\
\hline $\mathrm{Na}\left(\mathrm{mg} \mathrm{L}^{-1}\right)$ & $128.06 \pm 23.82$ & 88.50 & 168.67 \\
\hline $\mathrm{Na} / \mathrm{K}$ & $0.63 \pm 0.13$ & 0.38 & 0.82 \\
\hline $\mathrm{Al}\left(\mathrm{mg} \mathrm{L}^{-1}\right)$ & $5.57 \pm 0.77$ & 4.68 & 6.78 \\
\hline $\mathrm{B}\left(\mathrm{mg} \mathrm{L}^{-1}\right)$ & $4.07 \pm 3.27$ & 0.69 & 11.82 \\
\hline $\mathrm{Cu}\left(\mathrm{mg} \mathrm{L}^{-1}\right)$ & $0.42 \pm 0.06$ & 0.36 & 0.54 \\
\hline $\operatorname{Li}\left(\mathrm{mg} \mathrm{L}^{-1}\right)$ & $1.31 \pm 0.17$ & 1.24 & 1.77 \\
\hline $\mathrm{Zn}\left(\mathrm{mg} \mathrm{L}^{-1}\right)$ & $7.37 \pm 0.92$ & 6.90 & 9.80 \\
\hline
\end{tabular}

rameters. Descriptive analysis (means $\pm \mathrm{SD}, p<0.05$ ) and the normality test were performed between the data in the SPSS 17 program.

\section{Results}

Some motility parameters were evaluated characterizing velocities (VSL, VCL, and VAP) and movement styles (LIN, BCF, ALH and MAD) in sperm cells and semen seminal plasma contents of Capoeta trutta (Table 1). Sperm cell concentration ranged from 7.5 to 11.84 $($ mean \pm SE: $9.44 \pm 1.72) \times 10^{9}$ sperm cell $\mathrm{mL}^{-1}$. The velocities of sperm cells were found: the straight line velocity (VSL, $52.84 \pm 6.32 \mu \mathrm{m} \mathrm{s}^{-1}$ ), the curvilinear velocity (VCL, $103.86 \pm 22.67 \mu \mathrm{m} \mathrm{s}^{-1}$ ), and the angular path velocity (VAP, $\left.66.71 \pm 11.02 \mu \mathrm{m} \mathrm{s}^{-1}\right)$. In the semen seminal plasma ions $\mathrm{K}\left(206.84 \pm 20.61 \mathrm{mg} \mathrm{L}^{-1}\right)$ and $\mathrm{Na}\left(128.06 \pm 23.82 \mathrm{mg} \mathrm{L}^{-1}\right)$ were the predominant ions. $\mathrm{Ca}$ and $\mathrm{Mg}$ were measured to be $14.05 \pm 4.13$ and $3.35 \pm 0.44 \mathrm{mg} \mathrm{L}^{-1}$, respectively.

Positive relationships were found between $\mathrm{K}, \mathrm{Na}, \mathrm{Ca}$, and $\mathrm{Mg}$ in semen seminal plasma and the values of VSL, VCL, and VAP in sperm cell velocities. However, the partially strong relationship with the VCL value was with $\mathrm{K}\left(R^{2}=\right.$ $0.67 ; p<0.05)$, while it was moderate with $\mathrm{Mg}\left(R^{2}=0.48\right.$; $p<0.05)$ and comparable with $\mathrm{Na}\left(R^{2}=0.17 ; p<0.05\right)$ or Ca $\left(R^{2}=0.34 ; p<0.05\right)$ (Fig. 1, Table 3$)$. The correlation between the contents of semen seminal plasma and motility parameters of sperm cells is shown in Table 2. According to our results, $\mathrm{K}$ and $\mathrm{Mg}$ ions correlated positively with the VCL value of sperm cells, $r=0.820$ and $r=0.696, p<0.01$, respectively. In this study, there was no correlation between the trace metals and sperm cell velocities according to our results (Table 2).

\section{Discussion}

The assessment semen quality can give great information for gamete management and the protocols of artificial reproduction of wild fish species in captivity (Alavi et al., 2006; Mylonas et al., 2010). Therefore, we aimed to determine gamete quality parameters on a domestic fish species, Capoeta trutta in the Euphrates River. In this study, we analyzed the relationships between sperm cell velocities and semen seminal plasma contents in Capoeta trutta. Thereby, the values of VSL, VCL, and VAP were higher than those for Barbus sharpeyi, Catla catla, and Labeo rohita (Kalbassi et al., 2013); they were similar to Labeo calbasu, Cirrhinus mrigala, Hypophthalmichthys molitrix, and Ctenopharyngodon idella (Verma et al., 2009). However, the sperm cell density of Capoeta trutta $\left(9.44 \times 10^{9}\right)$ was found to be more than the sperm cell density of Liza abu $\left(4.27 \times 10^{9}\right)$ (Şahinöz et al., 2008) and Capoeta damascina $\left(\sim 5 \times 10^{9}\right)$ (Zadmajid et al., 2018), while it was found to be less for Barbus grypus $\left(18.8 \times 10^{9}\right)$ (Khodadadi et al., 2016), Cyprinus carpio $\left(16.96-18.81 \times 10^{9}\right)(C e j k o$ et al., 2014), and Ctenopharyngodon idella $\left(15.43 \times 10^{9}\right)$ (Bozkurt et al., 2008). These differences can be caused by hormonal treatments which increase sperm cell density in some fish species (Zadmajid et al., 2018).

There are very important ions $\left(\mathrm{Na}^{+}, \mathrm{K}^{+}, \mathrm{Ca}^{2+}, \mathrm{Mg}^{2+}\right.$, $\mathrm{HCO}_{3}^{-}$etc.) in semen seminal plasma which support the viability, motility, or immobilization of sperm cells which are immobilized in the testes and semen seminal plasma in teleost fish species. The initial motility depends on the conditions of the fertilization environment (Alavi and Cosson, 2006; Browne et al., 2015; Dzyuba and Cosson, 2014). For example, the motility of rainbow trout sperm cells was inhibited with high concentrations of the $\mathrm{K}^{+}$ion (Alavi and Cosson, 2006). However, there is a positive correlation between sperm cell velocity and $\mathrm{Ca}$ ion content of semen seminal plasma (Alavi et al., 2011; Dziewulska and Domagała, 2013; Nynca et al., 2014). On the other hand, $\mathrm{K}^{+}$ions completely inhibited sperm cell activation (Alavi et al., 2011; Ögretmen et al., 2014).

In our study, $\mathrm{Na}^{+}$and $\mathrm{K}^{+}$were seen as the main electrolytes involved in the maintenance of the osmolality of semen seminal plasma (Alavi and Cosson, 2006; Morisawa et al., 1983; Zadmajid, 2016). However, a positive correlation has been reported among osmolality, $\mathrm{Na}^{+}$, and $\mathrm{Cl}^{-}$ in the seminal plasma of Alburnus alburnus (Lahnsteiner et al., 1996). This status can occur due to the different species (Alavi and Cosson, 2006; Verma et al., 2009). 
Table 2. Pearson correlations between sperm cell motility and semen seminal plasma contents of Capoeta trutta.

\begin{tabular}{|c|c|c|c|c|c|c|c|c|c|c|c|c|c|c|c|}
\hline & \multicolumn{15}{|c|}{ Pearson correlations } \\
\hline & VSL & VCL & VAP & LIN & $\mathrm{BCF}$ & ALH & MAD & $\mathrm{Ca}$ & K & $\mathrm{Mg}$ & $\mathrm{Na}$ & $\mathrm{Al}$ & B & $\mathrm{Cu}$ & $\mathrm{Li}$ \\
\hline VCL & 0.555 & & & & & & & & & & & & & & \\
\hline VAP & $0.755^{\mathrm{a}}$ & 0.504 & & & & & & & & & & & & & \\
\hline LIN & -0.357 & -0.580 & -0.154 & & & & & & & & & & & & \\
\hline $\mathrm{BCF}$ & 0.130 & 0.574 & 0.023 & -0.371 & & & & & & & & & & & \\
\hline ALH & 0.021 & -0.131 & 0.223 & 0.546 & -0.349 & & & & & & & & & & \\
\hline MAD & -0.390 & $-0.803^{\mathrm{b}}$ & -0.183 & $0.695^{\mathrm{a}}$ & -0.231 & 0.299 & & & & & & & & & \\
\hline $\mathrm{Ca}$ & 0.242 & 0.587 & 0.009 & -0.590 & 0.394 & -0.537 & -0.575 & & & & & & & & \\
\hline K & 0.451 & $0.820^{\mathrm{b}}$ & 0.362 & -0.496 & 0.375 & 0.004 & $-0.823^{\mathrm{b}}$ & 0.361 & & & & & & & \\
\hline $\mathrm{Mg}$ & 0.324 & $0.696^{\mathrm{a}}$ & 0.452 & -0.605 & 0.244 & 0.221 & -0.609 & 0.305 & $0.716^{\mathrm{a}}$ & & & & & & \\
\hline $\mathrm{Na}$ & -0.313 & 0.410 & -0.135 & 0.043 & 0.204 & -0.002 & -0.471 & 0.279 & 0.459 & 0.321 & & & & & \\
\hline $\mathrm{Al}$ & 0.268 & 0.423 & 0.355 & $-0.644^{\mathrm{a}}$ & 0.056 & 0.103 & -0.537 & -0.063 & 0.608 & $0.820^{\mathrm{b}}$ & 0.075 & & & & \\
\hline B & -0.131 & 0.047 & 0.059 & 0.131 & -0.345 & -0.356 & -0.198 & 0.278 & -0.062 & -0.296 & 0.319 & -0.365 & & & \\
\hline $\mathrm{Cu}$ & 0.061 & 0.108 & 0.398 & -0.310 & -0.187 & -0.294 & -0.199 & -0.214 & 0.007 & 0.133 & -0.057 & 0.438 & 0.381 & & \\
\hline $\mathrm{Li}$ & -0.005 & 0.342 & 0.170 & -0.377 & 0.369 & 0.075 & -0.253 & -0.328 & 0.337 & 0.468 & 0.021 & $0.691^{\mathrm{a}}$ & -0.385 & 0.508 & \\
\hline $\mathrm{Zn}$ & -0.007 & 0.354 & 0.208 & -0.419 & 0.322 & 0.067 & -0.288 & -0.305 & 0.373 & 0.532 & 0.053 & $0.756^{\mathrm{a}}$ & -0.348 & 0.558 & $0.992^{b}$ \\
\hline
\end{tabular}

${ }^{\mathrm{a}}$ Correlation is significant at the 0.05 level (two-tailed). ${ }^{\mathrm{b}}$ Correlation is significant at the 0.01 level (two-tailed).

Potassium and VCL

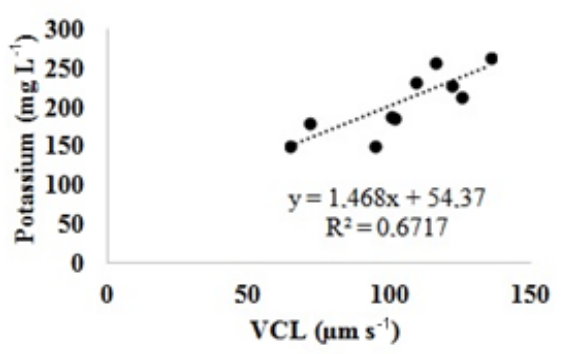

Sodium and VCL

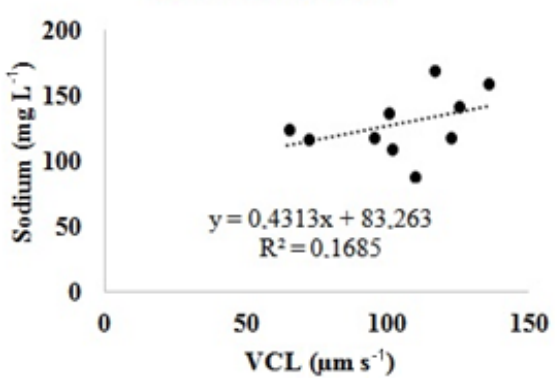

Calcium and VCL

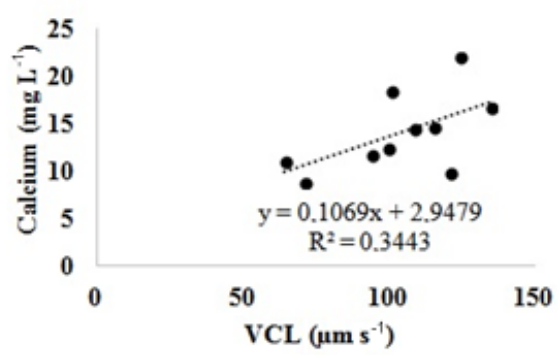

Magnesium and VCL

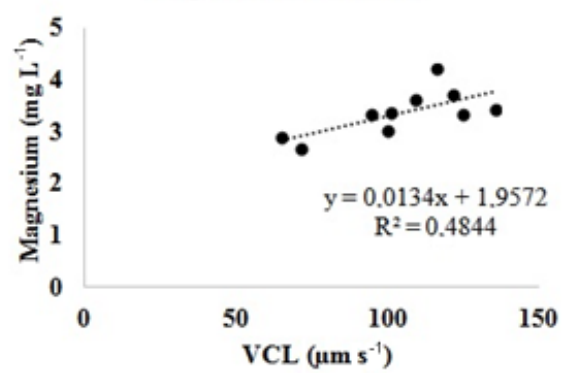

Figure 1. Linear regression graphics between some ions of semen seminal plasma and the VCL value of sperm cell in Capoeta trutta.

Positive linear regression relationships (weak in VSL and VAP in Table 3, moderately strong in VCL in Fig. 1) were found between velocities and $\mathrm{Na}^{+}, \mathrm{K}^{+}, \mathrm{Mg}$, and $\mathrm{Ca}^{2+}$ in the semen seminal plasma of Capoeta trutta. In some teleosts, some researchers have found a positive relationship between sperm cell motility and $\mathrm{K}^{+}$and $\mathrm{Na}^{+}$of seminal plasma (Alavi and Cosson, 2006; Bozkurt et al., 2008; Lahnsteiner et al., 1996) and $\mathrm{Ca}^{2+}$ of northern pike Esox lucius (Siddique et al., 2016a). However, the ratio of $\mathrm{Na}^{+} / \mathrm{K}^{+}$in the semen seminal plasma is vital in understanding the characteristics of fish sperm cell motility (Alavi and Cosson, 2006). The ratio of $\mathrm{Na}^{+} / \mathrm{K}^{+}$in the semen seminal plasma of Capoeta trutta was determined to be about $1: 2$, and it was lower than that for northern pike (Siddique et al., 2016b), some species of Salmonidae and Acipenseridae (Alavi and Cosson, 2006), and Barbus grypus (Khodadadi et al., 2016). However, it was parallel with Barbus sharpeyi (Alavi et al., 2010), Ctenopharyngodon idella (Bozkurt et al., 2008), and Cyprinus carpio (Bozkurt et al., 2009). These differences were probably present due to the individual characteristics of the species (Verma et al., 2009).

In conclusion, sperm cells generally move on a straight or slightly curved route after activation, which was found to be similar to and/or closely comparable to the results of some 
Table 3. Linear regression relationship between some ions of semen seminal plasma and the velocities of sperm cells in Capoeta trutta.

\begin{tabular}{lll}
\hline Parameters & Regression equation & Regression square \\
\hline Potassium-VSL & $y=2.90 x+53.59$ & $R^{2}=0.20$ \\
Potassium-VAP & $y=1.35 x+117.72$ & $R^{2}=0.13$ \\
Calcium-VSL & $y=0.16 x+5.67$ & $R^{2}=0.06$ \\
Calcium-VAP & $y=0.00 x+13.83$ & $R^{2}=0.00$ \\
Sodium-VSL & $y=-1.18 x+190.46$ & $R^{2}=0.10$ \\
Sodium-VAP & $y=-0.29 x+147.58$ & $R^{2}=0.02$ \\
Magnesium-VSL & $y=0.02 x+2.17$ & $R^{2}=0.11$ \\
Magnesium-VAP & $y=0.02 x+2.15$ & $R^{2}=0.20$ \\
\hline
\end{tabular}

authors according to the obtained parameters (Alavi et al., 2014; Fitzpatrick et al., 2008). Trace metals such as $\mathrm{Zn}, \mathrm{Al}$, $\mathrm{B}, \mathrm{Li}$, and $\mathrm{Cu}$ in semen seminal plasma were not correlated with sperm cell velocities. A similar status was confirmed for $\mathrm{Zn}$ in human semen (Bassey et al., 2013), while this was not the case for $\mathrm{Zn}$ in common carp semen (Kovacik et al., 2018) and human semen (Vickram et al., 2013), and for $\mathrm{Zn}$ and $\mathrm{Cu}$ in bovine semen (Tvrdá et al., 2013). These differences are probably due to the individual characteristics of the species (Verma et al., 2009), the activity of male reproductive accessory organs (Alavi et al., 2004), and the metal pollution of water (Acosta et al., 2016).

Finally, our results have shown that seminal plasma ions such as $\mathrm{Na}^{+}, \mathrm{K}^{+}, \mathrm{Mg}$, and $\mathrm{Ca}^{2+}$ were correlated with sperm cell velocities, while there is only the partially strong relationship between the VCL value and $\mathrm{K}^{+}$ion of sperm seminal plasma. However, we are hopeful that our data can lead to a better understanding of fertilization mechanisms of Capoeta trutta sperm cells because the knowledge of sperm cell motility and semen seminal plasma contents is a prerequisite for the successful assessment of the reproductive capacity of wild fish species.

Data availability. The data used in the present study are confidential and therefore not publicly available. 


\section{Appendix A}

\begin{tabular}{ll}
\hline Abbreviations and their definitions & \\
\hline VSL & the straight line velocity of sperm cell \\
VCL & the curvilinear velocity of sperm cell \\
VAP & the angular path velocity of sperm cell \\
LIN & the linearity of sperm cell \\
BCF & the beat cross frequency of sperm cell \\
$\mathrm{ALH}$ & the amplitude of lateral displacement of the sperm cell head \\
$\mathrm{MAD}$ & the mean angular displacement of sperm cell \\
$\mathrm{Ca}$ & calcium \\
$\mathrm{K}$ & potassium \\
$\mathrm{Mg}$ & magnesium \\
$\mathrm{Na}$ & sodium \\
$\mathrm{Al}$ & aluminum \\
$\mathrm{B}$ & boron \\
$\mathrm{Cu}$ & copper \\
$\mathrm{Li}$ & lithium \\
$\mathrm{Zn}$ & zinc
\end{tabular}


Author contributions. MEÖ designed the experimental setup. MEÖ and SE carried out the samplings. Measurements and chemical analyses were conducted by MEÖ, SE, and ZM. The statistical and scientific assessment of data was processed by MEÖ and SE. The manuscript was written by MEÖ with contributions from all coauthors.

Competing interests. The authors declare that they have no conflict of interest.

Review statement. This paper was edited by Manfred Mielenz and reviewed by two anonymous referees.

\section{References}

Acosta, I. B., Junior, A. S. V., e Silva, E. F., Cardoso, T. F., Caldas, J. S., Jardim, R. D., and Corcini, C. D.: Effects of exposure to cadmium in sperm cells of zebrafish, Danio rerio, Toxicol. Reports, 3, 696-700, https://doi.org/10.1016/j.toxrep.2016.08.002, 2016.

Alavi, S. M. H. and Cosson, J.: Sperm motility in fishes. (II) Effects of ions and osmolality: A review, Cell Biol. Int., 30, 1-14, https://doi.org/10.1016/j.cellbi.2005.06.004, 2006.

Alavi, S. M. H., Cosson, J., Karami, M., Abdolhay, H., and Amiri, B. M.: Chemical composition and osmolality of seminal fluid of Acipenser persicus; their physiological relationship with sperm motility, Aquac. Res., 35, 1238-1243, https://doi.org/10.1111/j.1365-2109.2004.01132.x, 2004.

Alavi, S. M. H., Jorfi, E., Hatef, A., and Saheb Mortezavi, S. A.: Sperm motility and seminal plasma characteristics in Barbus sharpeyi (Günther, 1874), Aquac. Res., 41, 688-694, https://doi.org/10.1111/j.1365-2109.2010.02600.x, 2010.

Alavi, S. M. H., Gela, D., Rodina, M., and Linhart, O.: Roles of osmolality, calcium - Potassium antagonist and calcium in activation and flagellar beating pattern of sturgeon sperm, Comp. Biochem. Physiol., 160, 166-174, https://doi.org/10.1016/j.cbpa.2011.05.026, 2011.

Alavi, S. M. H., Matsumura, N., Shiba, K., Itoh, N., Takahashi, K. G., Inaba, K., and Osada, M.: Roles of extracellular ions and $\mathrm{pH}$ in 5-HT-induced sperm motility in marine bivalve, Reproduction, 147, 331-345, https://doi.org/10.1530/REP-13-0418, 2014.

Bassey, I. E., Essien, O. E., Udoh, A. E., Imo, I. U., and Effiong, I. O.: Seminal Plasma Selenium, Calcium, Magnesium and Zinc Levels in Infertile Men, J. Med. Sci., 13, 483-487, https://doi.org/10.3923/jms.2013.483.487, 2013.

Billard, R. and Cosson, M. P.: Some problems related to the assessment of sperm motility in freshwater fish, J. Exp. Zool., 261, 122-131, https://doi.org/10.1002/jez.1402610203, 1992.

Bobe, J. and Labbé, C.: Egg and sperm quality in fish, Gen. Comp. Endocrinol., 165, 535-548, https://doi.org/10.1016/j.ygcen.2009.02.011, 2010.

Bozkurt, Y., Ögretmen, F., Erçin, U., and Yildiz, Ü.: Seminal plasma composition and its relationship with physical spermatological parameters of Grass carp (Ctenopharyngodon idella) semen: With emphasis on sperm motility, Aquac. Res., 39, 1666-1672, https://doi.org/10.1111/j.1365-2109.2008.02041.x, 2008.
Bozkurt, Y., Ogretmen, F., Secer, F. S., and Ercin, U.: Effects of seminal plasma composition on sperm motility in mirror carp (Cyprinus carpio), Isr. J. Aquac.-Bamidgeh, 61, 307-314, 2009.

Browne, R. K., Kaurova, S. A., Uteshev, V. K., Shishova, N. V., McGinnity, D., Figiel, C. R., Mansour, N., Agnew, D., Wu, M., Gakhova, E. N., Dzyuba, B., and Cosson, J.: Sperm motility of externally fertilizing fish and amphibians, Theriogenology, 83, 1-13, https://doi.org/10.1016/j.theriogenology.2014.09.018, 2015.

Cabrita, E., Martínez-Páramo, S., Gavaia, P. J., Riesco, M. F., Valcarce, D. G., Sarasquete, C., Herráez, M. P., and Robles, V.: Factors enhancing fish sperm quality and emerging tools for sperm analysis, Aquaculture, 432, 389-401, https://doi.org/10.1016/j.aquaculture.2014.04.034, 2014.

Cejko, B. I., Krejszeff, S., Judycka, S., Sarosiek, B., Dietrich, M., Kucharczyk, D., and Kowalski, R. K.: Sperm quality and selected biochemical markers of seminal plasma at the beginning of the reproductive period of common carp, Cyprinus carpio L., Aquac. Int., 22, 111-122, https://doi.org/10.1007/s10499-0139672-3, 2014.

Ciereszko, A. and Dabrowski, K.: Estimation of sperm concentration of rainbow trout, whitefish and yellow perch using a spectrophotometric technique, Aquaculture, 109, 367-373, https://doi.org/10.1016/0044-8486(93)90175-X, 1993.

Cosson, M. P., Billard, R., and Letellier, L.: Rise of internal $\mathrm{Ca}^{2+}$ accompanies the initiation of trout sperm motility, Cell Motil. Cytoskel., 14, 424-434, https://doi.org/10.1002/cm.970140312, 1989.

Demirsoy, A. (Eds.): Basic Rules of Life, Vertebrates/Anamniyota, Volume III, Part I, Meteksan Publications, Ankara, Turkey, 1993.

Dziewulska, K. and Domagała, J.: Effect of $\mathrm{pH}$ and cation concentrations on spermatozoan motility of sea trout (Salmo trutta m. trutta L.), Theriogenology, 79, 48-58, https://doi.org/10.1016/j.theriogenology.2012.09.008, 2013.

Dzyuba, V. and Cosson, J.: Motility of fish spermatozoa: from external signaling to flagella response, Reprod. Biol., 14, 165-175, https://doi.org/10.1016/j.repbio.2013.12.005, 2014.

Esmaeili, H. R., Coad, B. W., Gholamifard, A., and Teimory, A.: Annotated checklist of the freshwater fishes of Iran, Zoosystematica Ross., 19, 361-386, 2010.

Fauvel, C., Suquet, M., and Cosson, J.: Evaluation of fish sperm quality, J. Appl. Ichthyol., 26, 636-643, https://doi.org/10.1111/j.1439-0426.2010.01529.x, 2010.

Fitzpatrick, J. L., Nadella, S., Bucking, C., Balshine, S., and Wood, C. M.: The relative sensitivity of sperm, eggs and embryos to copper in the blue mussel (Mytilus trossulus), Comp. Biochem. Physiol., 147, 441-449, https://doi.org/10.1016/j.cbpc.2008.01.012, 2008.

Freyhof, J.: Capoeta trutta, The IUCN red list of threatened species, e.T19027513A19222908, available at: http://iucnredlist. org/details/19027513/0 (last access: 24 September 2019), 2014.

Kalbassi, M. R., Lorestani, R., and Ghafle M. J.: Analysis of saline activator solution effects on sperm quality indices of Barbus sharpeyi by Image J software, Iran. J. Fish. Sci., 12, 357-377, https://doi.org/10.3168/jds.2017-12732, 2013.

Khodadadi, M., Arab, A., and Jaferian, A.: A preliminary study on sperm morphology, motility and composition of seminal plasma of Shirbot, Barbus grypus, Turkish J. Fish. Aquat. Sci., 16, 947951, https://doi.org/10.4194/1303-2712-v16_4_22, 2016. 
Kovacik, A., Tirpak, F., Tomka, M., Miskeje, M., Tvrda, E., Arvay, J., Andreji, J., Slanina, T., Gabor, M., Hleba, L., Fik, M., Jambor, T., Cisarova, M., and Massanyi, P.: Trace elements content in semen and their interactions with sperm quality and RedOx status in freshwater fish Cyprinus carpio: A correlation study, J. Trace Elem. Med. Biol., 50, 399-407, https://doi.org/10.1016/j.jtemb.2018.08.005, 2018.

Lahnsteiner, F., Berger, B., Weismann, T., and Patzner, R. A.: Motility of spermatozoa of Alburnus alburnus (Cyprinidae) and its relationship to seminal plasma composition and sperm metabolism, Fish Physiol. Biochem., 15, 167-179, https://doi.org/10.1007/BF01875596, 1996.

Li, Z. H., Li, P., Dzyuba, B., and Randak, T.: Influence of environmental related concentrations of heavy metals on motility parameters and antioxidant responses in sturgeon sperm, Chem. Biol. Interact., 188, 473-477, https://doi.org/10.1016/j.cbi.2010.09.005, 2010.

Linhart, O., Rodina, M., and Cosson, J.: Cryopreservation of sperm in common carp Cyprinus carpio: Sperm motility and hatching success of embryos, Cryobiology, 41, 241-250, https://doi.org/10.1006/cryo.2000.2284, 2000.

Lorenzen, K., Beveridge, M. C. M., and Mangel, M.: Cultured fish: integrative biology and management of domestication and interactions with wild fish, Biol. Rev., 87, 639-660, https://doi.org/10.1111/j.1469-185X.2011.00215.x, 2012.

Massanyi, P., Weis, J., Lukac, N., Trandzik, J., and Bystricka, J.: Cadmium, zinc, copper, sodium and potassium concentrations in rooster and turkey semen and their correlation, J. Environ. Sci. Heal. Pt. A, 43, 563-565, https://doi.org/10.1080/10934520701796655, 2008.

Morisawa, M., Suzuki, K., Shimizu, H., Morisawa, S., and Yasuda, K.: Effects of osmolality and potassium on motility of spermatozoa from freshwater cyprinid fishes, J. Exp. Biol., 107, 95-103, https://doi.org/10.1016/j.jallcom.2014.06.123, 1983.

Mylonas, C. C., Fostier, A., and Zanuy, S.: Broodstock management and hormonal manipulations of fish reproduction, Gen. Comp. Endocrinol., 165, 516-534, https://doi.org/10.1016/j.ygcen.2009.03.007, 2010.

Nynca, J., Dietrich, G. J., Dobosz, S., Grudniewska, J., and Ciereszko, A.: Effect of cryopreservation on sperm motility parameters and fertilizing ability of brown trout semen, Aquaculture, 433, 62-65, https://doi.org/10.1016/j.aquaculture.2014.05.037, 2014.

Ögretmen, F., Gölbaşi, S., and Inanan, B. E.: Inhibitory effect of $\mathrm{K}+$ and $\mathrm{Ca} 2+$ concentrations, $\mathrm{pH}$, and osmolality of activation solution on motility of shabut (Barbus grypus Heckel 1843) spermatozoa, Turkish J. Vet. Anim. Sci., 38, 245-252, https://doi.org/10.3906/vet-1308-9, 2014.

Özgür, M. E., Yumuşakbaş, H., Dağli, M., and Erdoğan, S.: Comparison of some elements in sperm seminal plasma of rainbow trout (Oncorhynchus mykiss) and Brown trout (Salmo trutta fario), J. Appl. Biol. Sci., 9, 64-67, 2015.

Özgür, M. E., Okumuş, F., and Kocamaz A. F.: A Novel Computer Assisted Sperm Analyzer for Assessment of Spermatozoa Motility in Fish; BASA-Sperm Aqua, El-Cezeri Fen ve Mühendislik Derg., 6, 208-219, https://doi.org/10.31202/ecjse.486342, 2019.
Rurangwa, E., Kime, D. E., Ollevier, F., and Nash, J. P.: The measurement of sperm motility and factors affecting sperm quality in cultured fish, Aquaculture, 234, 1-28, https://doi.org/10.1016/j.aquaculture.2003.12.006, 2004.

Şahinöz, E., Aral, F., and Dogu, Z.: Determination of spermatological properties of male Liza abu (Heckel, 1843) in Atatürk Dam Lake, Şanliurfa, Fish Physiol. Biochem., 34, 7176, https://doi.org/10.1007/s10695-007-9148-3, 2008.

Siddique, M., Linhart, O., Kujawa, R., Krejszeff, S., and Butts, I.: Composition of seminal plasma and ovarian fluid in Ide Leuciscus idus and Northern pike Esox lucius, Reprod. Domest. Anim., 51, 960-969, https://doi.org/10.1111/rda.12773, 2016.

Slivkova, J., Popelkova, M., Massanyi, P., Toporcerova, S., Stawarz, R., Formicki, G., Lukac, N., Putała, A., and Guzik, M.: Concentration of trace elements in human semen and relation to spermatozoa quality, J. Environ. Sci. Heal. Pt. A, 44, 370-375, https://doi.org/10.1080/10934520802659729, 2009.

Tanimoto, S. and Morisawa, M.: Roles for Potassium and Calcium Channels in the Initiation of Sperm Motility in Rainbow Trout, ( $\mathrm{K}^{+} / \mathrm{Ca}^{2+} /$ channel/sperm motility/rainbow trout), Dev. Growth Differ., 30, 117-124, https://doi.org/10.1111/j.1440169X.1988.00117.x, 1988.

Tvrdá, E., Lukáč, N., Schneidgenová, M., Lukáčová, J., Szabó, C., Goc, Z., Greń, A., and Massányi, P.: Impact of Seminal Chemical Elements on the Oxidative Balance in Bovine Seminal Plasma and Spermatozoa, J. Vet. Med., 1-8, https://doi.org/10.1155/2013/125096, 2013.

Verma, D. K., Routray, P., Dash, C., Dasgupta, S., and Jena, J. K.: Physical and biochemical characteristics of semen and ultrastructure of spermatozoa in six carp species, Turkish J. Fish. Aquat. Sci., 9, 67-76, 2009.

Vickram, S., Muthugadhalli, S., Jayaraman, G., Kamini, R., Ramesh Pathy, M., and Sridharan, B.: Influence of trace elements and their correlation with semen quality in fertile and infertile subjects, Turkish J. Med. Sci., 43, 1000-1007, https://doi.org/10.3906/sag-1211-54, 2013.

Yuyan, L., Junqing, W., Wei, Y., Weijin, Z., and Ersheng, G.: Are serum zinc and copper levels related to semen quality?, Fertil. Steril., 89, 1008-1011, https://doi.org/10.1016/j.fertnstert.2007.04.028, 2008.

Zadmajid, V.: Comparative effects of human chorionic gonadotropin (hCG) and Ovaprim ${ }^{\mathrm{TM}}$ (sGnRHa + domperidone) on the reproductive characteristics of wild-caught male Longspine scraper, Capoeta trutta (Heckel, 1843), Aquaculture, 463, 7-15, https://doi.org/10.1016/j.aquaculture.2016.05.029, 2016.

Zadmajid, V., Bashiri, S., Sharafi, N., and Butts, I. A. E.: Effect of hCG and Ovaprim ${ }^{\text {тм }}$ on reproductive characteristics of male Levantine scraper, Capoeta damascina (Valenciennes, 1842), Theriogenology, 115, 45-56, https://doi.org/10.1016/j.theriogenology.2018.04.017, 2018. 